\title{
SUDAN'S TEA LADIES AND THE LEGACY OF SLAVERY
}

\author{
MACIEJ KURCZ \\ INSTITUTE OF ETHNOLOGY AND CULTURAL ANTHROPOLOGY \\ UNIVERSITY OF SILESIA IN KATOWICE
}

\begin{abstract}
This paper presents the institution of roadside mini-cafes run by women - mostly poor migrants from peripheral or war-torn regions of Sudan - on Forty Days Road Street, one of the main streets of Omdurman. These cafes are not only one of the many examples of women's informal activism in an urban environment, but also an institution in which the legacy of slavery is present. This dates back to precolonial times when the peoples of the Nile valley were slave-raiding and slave-owning. The author looks at the institution of roadside mini-cafe as something particularly important for the urban iconography of power, in which - using the terms of structural anthropology - a series of oppositions are materialised: formal/ informal, male/female, dominant/subordinate and Middle Eastern/African. The relations to slavery hidden in this particular institution help city dwellers (mostly men from the Muslim majority and Arab culture) in arranging hierarchies, rivalry and legitimating status. Gender and informality are particularly meaningful in this context as both strengthen the situation of radical inequality, intensify and constitute politics of dominance on the one hand and of subordination on the other. This paper is based on ethnographic research which was undertaken in the Khartoum agglomeration in 2013.
\end{abstract}

W artykule omawiana jest instytucja przydrożnych kawiarenek znajdujących się przy ul. Czterdziestodniowej, jednej z głównych arterii komunikacyjnych Omdurmanu, prowadzonych przez kobiety, w szczególności migrantki z peryferyjnych obszarów Sudanu. Dla autora fenomen ten nie jest tylko przykładem nieformalnej, kobiecej przedsiębiorczości, ale także instytucją, w której daje o sobie znać dziedzictwo niewolnictwa. Autor przekonuje, że „kobiety od herbaty” rzucają nieco światła na relacje między mieszkańcami Sudanu, w szczególności między „jaśniejszymi”, zorientowanymi na kulturę arabską i islam, a „ciemniejszymi”, żyjącymi na geograficznych peryferiach. W relacjach tych - używając języka antropologii strukturalnej materializują się serie opozycji: formalny/nieformalny, męski/żeński, dominujący/podporządkowany, bliskowschodni / afrykański. Artykuł jest plonem obserwacji etnograficznych, prowadzonych w chartumskiej aglomeracji w 2013 roku.

Ke yw ords: Sudan, slavery, citzy, women, ethnographic research

The economic reforms of the I980s, armed conflicts, the breakdown of state institutions in the I990s, and the "urban revolution" at the beginning of the new millennium have made the lives of large parts of African society much more difficult than ever before. In many countries, one of the negative effects of the above mentioned processes has been the resurgence of various forms of slavery. Its victims are the weakest: women, 
children and young people, displaced persons and labour migrants (Bales et al. 20II). Although the term "modern slavery", also referred to as "new slavery", is in common usage nowadays, it should be treated with caution as there is no universal agreement as to what practices can be considered modern enslavement. For some, this term includes all forms of gross human exploitation and trafficking. In this sense, this phenomenon is considered to have a global reach. For others, it is limited to those areas where legally owned and traded slaves were once to be found and thus a slavery continuum can be spoken about. Undoubtedly, discussions on this subject are often ideologically charged. For instance, in the Western media, contemporary African slavery is usually depicted as evidence of Africa's on-going primitivism. It seems that the key to understanding slavery is the ownership notion. In the historical Slavery Convention of 1926, slavery was defined as the state of subordination of one man to another. Today it is not so obvious. First of all, in today's world it is not possible to possess a slave legally and if one is in possession of one then this was done illegally. Slaveholders (not slave-owners) have no formal rights to the enslaved person, but also no obligations to him/her. An enslaved person today is created through violence or the threat of violence rather than in accordance with some law. In other words, modern slavery is a criminal act, a kind of theft of the body, work, identity, sexuality or simply the taking of someone's ability to decide their own fate. For this reason, slave practices are usually invisible to the naked eye; they are always tightly concealed and silenced. Therefore, in the context of post slavery studies, the most frequently asked questions involve when and how slavery is employed, who its victims are and which crypto-slavery practices are involved.

The contemporary practice of slavery is not really about having slaves - but rather the way they are treated as an effective tool for making money. In our world, a slave has been reduced to the role of a machine in the production process. Slavery is closely tied to labour. A modern slave is not a durable good but viewed as a mere commodity -one which can be bought, used and discarded at any time. Slaves have never been so cheap and their prices are determined by the law of supply and demand - and the fact that this phenomenon is coupled with the functioning of the global economy. Modern slavery results from a variety of phenomena (migration, neoliberal social divisions, gentrification and wars) and takes a variety of forms (human trafficking, slave labour, prostitution and forced marriage) (Bales 1999, I-6; Bales 2005, 9; O'Connell Davidson 20I5).

Sudan is a country that has been associated (rightly) with slavery for many years. During the second civil war in South Sudan (1983-2005), the activity of abducting and selling Dinka or Nuer women and children was practiced. Their price was not excessive due to regular tribal raids and extreme poverty. These phenomena generated a constant risk of falling into slavery for a large part of the South Sudan population. Later those who had been enslaved disappeared somewhere in Central and Northern Sudan. It turned out that, under the patronage of local, Muslim families, they usually became a cheap labour force (photo I). 


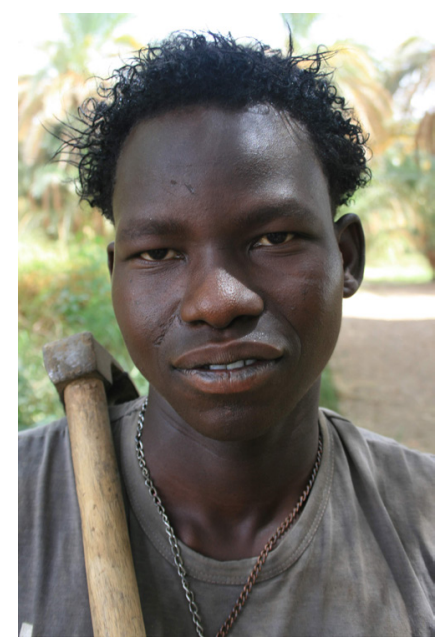

Photo I. A migrant from Nuba Hills, Ghaddar. Photo: M. Kurcz 2013.

Similar practices occurred during another Sudanese conflict - the war in Darfur. At that time a thousands of refugees were exposed to the relics of slavery. These were people who became internally displaced and were looking for shelter in Sudanese towns. Finally, in villages on the Nile of Northern Sudan the vestiges of domestic slavery can still be encountered today in the form of people with slave ancestry who form closed and most importantly servile communities (Kurcz 2007; Jok 2010, 4-5).

A good example of the existence of slavery in contemporary Sudan is the institution of roadside mini-cafes run by women - mostly poor migrants from peripheral or war-torn regions of Sudan - on Forty Days Road Street, one of the main streets of Omdurman (photo 2).

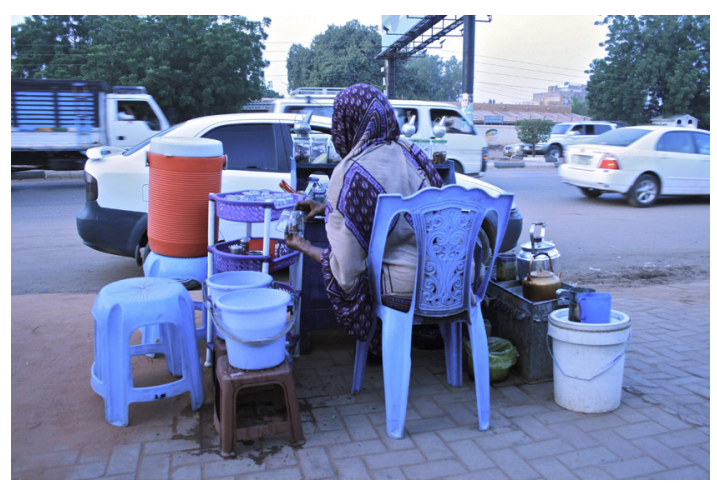

Photo 2. A "women of tea” on Forty Days Road Street, Omdurman. Photo: M. Kurcz 2013. 
I am of the belief that this is not only one of many examples of women's informal activity in an urban environment, but something much more meaningful for the local iconography of power. The power relationship hidden in this particular institution helps city dwellers (mostly men from the Muslim majority and Arab culture) to arrange hierarchies, rivalry and legitimize status. Gender and informality are particularly meaningful in this context as both strengthen the situation of radical inequality, intensify and constitute politics of dominance on the one hand, and of subordination on the other.

My ethnographic experience from Sudan makes me believe that the local concept of slavery extends not only to "descendants", but also to all those with an uncertain status - such as labour migrants in urban centres. Migration to the city does not always result in social or economic emancipation as migrants with a reduced status meet a sort of glass ceiling - where they are permanently pushed to the margins of urban life and join the ranks of the lumpenproletariat. They are forced to do poorly-paid jobs, hide their identity and culture, and accept the patronage of higher social classes.

The questions the author wishes to address include how the legacy of slavery in the case of Sudan's tea ladies is to be perceived, what this means for different groups of actors and finally, how slavery helps to organise social and economic relationships in an urban context.

\section{SLAVERY BORDERLAND}

A statement verging on a truism is that slavery has been practised in Sudan since time immemorial. It existed in all political organisations of pre-colonial Sudan (Kush, Meroe, Christina Nubia, Funj and Darfur). Within the entire Sahel zone, slavery was a tool for exercising authority (through which a state could reproduce its human resources) as well as being a highly profitable businesses. Slaves came from Nubia, but they were not Nubians. The Nuba Mountains, the borderland with Abyssinia, the marshes of the White Nile and Southern Dar Fartit (today known as Western Bahr al Ghazal) are all areas from which slaves have been taken at least since Medieval times (Johnson 20II, 2). For many centuries, in Sudan, a model of political geography was valid, in which a clear division into two different quality spaces was maintained: a political centre and much more extensive peripheries. All pre-colonial Sudanese countries had such a dual structure. This model is still valid to a large degree and is responsible for the country's internal problems and the maintenance of something close to what can be called social caste relationships.

As has been indicated, slavery has been an important sphere of Sudanese political organization- activity for centuries. During the Turco-Egyptian occupation, however, it rose dramatically. Slaves became one of the main instigators behind the Egyptian invasion of Sudan at the beginning of the $19^{\text {th }}$ century. The Egyptian governors of 
Sudan developed the practice of plundering raids in the south. Then slave hunters expanded their activities from areas of the Blue Nile or the Nuba Mountains into the heart of today's South Sudan. Nearly all communities inhabiting South Sudan today were the victims of slavers (photo 3).

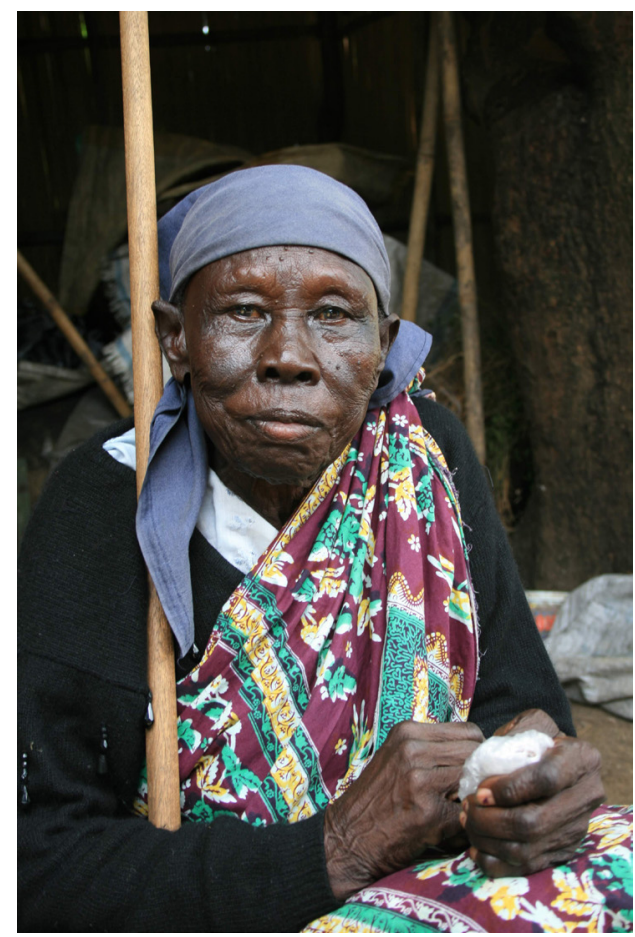

Photo 3. A women from the Madi tribe, one of the many societies of South Sudan affected by slavery, Juba. Photo: M. Kurcz 2008.

Men were transported to Aswan, where they were forced into the army as jihadiyya (slave-soldiers), whereas women and children were sold on site and treated as sources of revenue for merchants and local middlemen. Though officially government raids were abandoned at the beginning of the $19^{\text {th }}$ century, slavery still continued. It became the domain of private entrepreneurs such as Zubeir Rahma Mansur, who became an independent ruler in the Western part of Bahr al Ghazal, and conquered Darfur (Breidlid et al. 20I4,IO4-IO7).

After I860, when the Mahdist movement was established, the slave trade still did not disappear, but moved into the hands of natives, the Danagla Nubians and Shaigiya Arabs. In the South they were known as jallaba - due to a typical robe worn by Arabs (photo 4). 


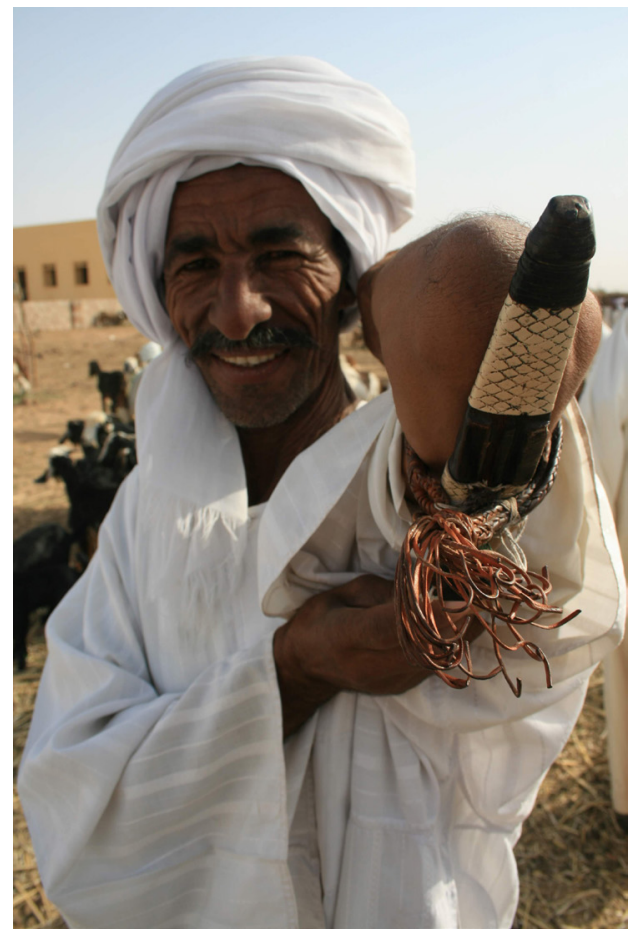

Photo 4. "Jallaba" - a merchant from Northern Sudan, Debba. Photo: M. Kurcz 2013.

Within the territories of the Luo, Bongo or Dinka people, the traders set up temporary slave factories - the so-called enclosures (from Arabic zaraib). These were places of contact between hunters-and-traders and representatives of local tribes who were intermediaries in acquiring people. Slave hunters were quite poor people, who supplemented their low income by means of slaves. Some of these slaves (juveniles and women) were sold in the local market or taken for personal use in the home regions (Breidlid et al. 20I4, II2-II3). It was then in the North that the possession of slaves probably became quite common. They were used in the field when needed or as cheap domestic servants. Black women, considered particularly attractive, became concubines or legal wives. A slave's fate was not doomed forever. A slave belonged to a community, participated in its life and could even become a legitimate member of this community. Usually they enjoyed little prestige, but were allowed to assimilate (for example by way of religious conversion). Becoming a Muslim, however, did not translate into increased freedom since their origin remained unchanged, and they were still dependent. The best they could be was a client (someone who needs permanent protection and representation) or a servant for a part of the society considered more 
noble. Slaves were expected to specialize in tasks which were not considered very prestigious. In the villages of the Northern Sudan, there was a strict relationship between a person's profession and social status due to slavery. This meant that slaves or their descendants specialized in certain categories of activities, such as pottery, moonshining or fishery. They were also present in the service sector

A very important element in all this was its gender structure. Most people abducted from the northern regions were juveniles and women. The latter were particularly valued because of their "versatility". A female slave could work in the field and look after the house. She was also allowed to undertake some small professional activities such as the production of alcohol and trading in the local bazaar. This resulted in her becoming economically independent with a "secret nest egg". Finally, sexual value was also important. A woman from the South was different from a local woman, since, as a rule, she was not circumcised. It made her a strong object of male desire but engendered ensuing fear and hate from local Muslim women. Thus slavery in Sudan, particularly of a domestic nature, was a clearly gendered phenomenon (Amir 2013).

In the second half of the nineteenth century the dichotomous division into the centre and periphery was consolidated into privileged and marginalized groups, white and black and masters and slaves. The nineteenth century was a time of great change. In the ideological dimension, certain areas of Sudan became what can be described as a slave borderland. Slaves in the northern provinces came mainly from the South resulting in the words "slave" and "black" becoming synonymous. This has led to a polarization of society based on race and the universal identification of non-Arab and non-Muslim parts of the population with low status - or even a lack of it. Slavery became part of the concept of "stranger". In other words, an almost caste system of hierarchy was created (Makris 2000, 26).

Though British colonialism in Sudan was focused, like everywhere else, on the exploitation of people and natural resources, ideologically it was presented as a humanitarian mission. The Sudan was exceptional in this respect since it had no clear economic value, and the British presence in this area was associated with Gordon's tragedy (I885) and Kitchener's famous victory at Omdurman (1898). Basically for these reasons the essence of the British Empire's presence was to prevent conflicts and civilise Africans (as was correctly expressed by anthropologist Janice Boddy). Institutions allegedly unworthy of modern man were to be fought against by brave Britons - female circumcision and slavery were at the top of the list. Unfortunately, the fight against slavery meant also its inclusion in colonial discourse as the local population became categorised and stratified. On one side there were fanatically religious, though more predisposed to rule, Arabs, while on the other there were the persecuted, though primitive, Africans. The latter, be it of their own fault or natural predisposition, were threatened with extinction. This was all because of Islamisation and Arabisation. In colonial times, egalitarianism 
and integration were not propagated, but instead and in accordance with the ideas of indirect rule, the existing hierarchical structures were strengthened. Hence in that period not only can the heritage of slavery be talked about, but also slavery par excellence. And so the British used the so-called "Nubian" military formation recruiting former slaves serving in the Turco-Egyptian army ${ }^{1}$. They were later used in various parts of East Africa and their descendants today form separate identities and demand ethnic minority-status. A similar situation arose in regards to domestic slavery. It is still tolerated, in accordance with the recommendation of Lord Kitchener himself, the hero of "reconquista" and the first General Governor of the Sudan:

"[S]lavery is not recognised in the Sudan, but as long as service is willingly rendered by servants to master it is unnecessary to interfere with the conditions existing between them" (Amir 2013, 49).

As a result, more than a hundred years after the formal prohibition of slavery, in Northern Sudan the living vestiges of this activity can still be seen. These are visible in the differentiation of people into "free" and "slave descendants" which is still of basic importance for the social structure (Barclay 1964, 237). Nearly every village in Northern Sudan has people called Sudaniyya ("Blacks"). They are the descendants of former slaves and almost every village between the $3^{\text {rd }}$ and $4^{\text {th }}$ cataracts ${ }^{2}$ is inhabited by at least several such families today. They form indigenous communities that still have a specific system of relationships in common with descendants of the former owners (Kurcz 2007, 70, 8I).

The practice of slavery in an independent Sudan is a separate issue. It is not a secret that slavery played a role in the military conflicts in South Sudan and Darfur and there is quite a lot of literature to confirm this. An assessment has been made that about ten to fifteen thousand women and children have been abducted since 1983. In 1987, according to human rights organisations, seven thousand women and children from Darfur and Kordofan became victims of slave-raiders - mostly representatives of Arab pastoralists (Jok 20IO, I-2). Not only have the victims of organised raids been exposed to slavery, but so also have all people fleeing war, hunger and economic poverty, coming under the umbrella term, the internally displaced. These people sought shelter in urban centres of Central and Northern Sudan, where they were housed in their outskirts in provisional camps. There, due to insufficient or limited humanitarian assistance, they were forced to find 'gainful employment' in the informal sector under the patronage of local Muslims. They were at the very bottom of the local social ladder and a good case in point are the tea ladies.

I So called "Nubians" were originally the ex slave-soldiers from Turco-Egyptian Sudan re-used by the British to create a native military force. Their descendants in Uganda and Kenya have developed a sense of identitity and nowdays fight for political recognition and the rights to the land.

2 The cataracts of the Nile are shallow lengths between Asuan and Khartoum. 
Sudanese teashops are a permanent fixture in every town, but are also places of importance from a social and economic point of view. They appeared on a large scale in the 1960s together with an influx of migrants from the war-torn South. Today it is the occupation of a variety of women's however, migrants from traditionally peripheral and problematic regions predominate in this sector. On the Forty Days Road - one of the main streets of Omdurman - can be found practically only women from the Nuba Mountains.

A little coffee shop is to be found at an important place, such as a junction or a restaurant. Only tea and coffee are served there, sometimes with snacks prepared on site. A coffee shop always goes hand in hand with another place. Its operation may coexist with a restaurant, a shop or a public institution. It may also be associated with an event, such as a football match or a Sufi ritual.

A teashop is quite simple and is composed of a small counter - cabinet. There, a woman keeps tins with tea, coffee, karkade (dried Hibiscus leaves), sugar and powdered milk. She also prepares beverages on it. She has two buckets used for washing the utensils - with clean and dirty water - a water canister a rudimentary stove (the so-called kanun), with two pots on it heated by charcoal, a container for grounds and a little stool for washing dishes. All are mini-size. Beverages are drunk from small glasses, typical of the entire Middle East region, which are served on a small tray. A customer sits on a stool, at a small table. Basically these are the ingredients of a roadside coffee shop (photo 5).

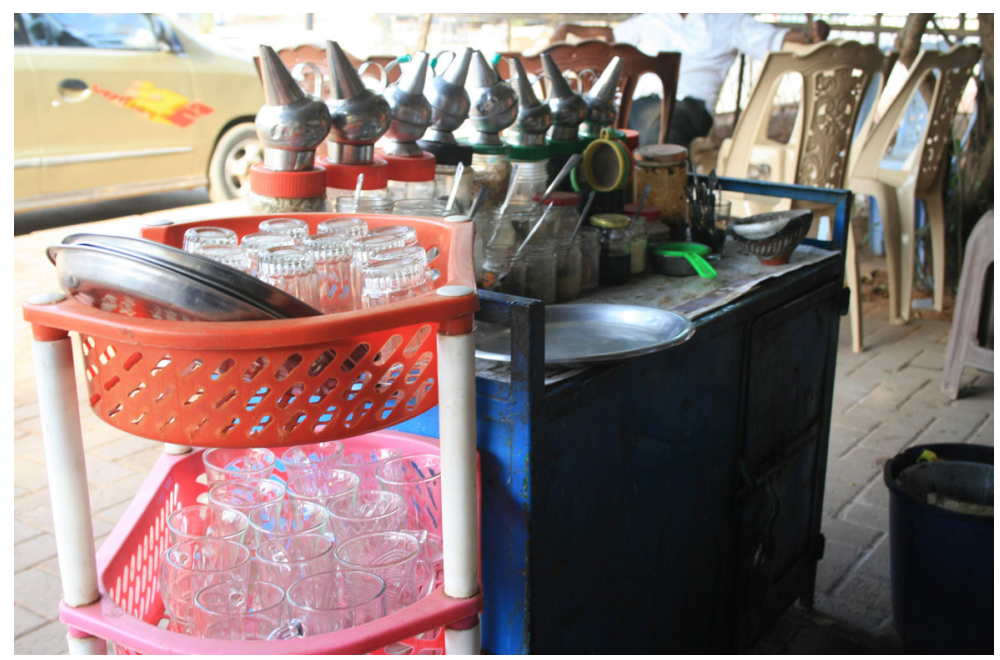

Photo 5. A place of work, Khartoum. Photo: M. Kurcz 2013. 
Everything is done noiselessly and automatically. A customer sits down and a serving woman puts a heaped spoonful of sugar into a glass, pours black tea directly from a pot (if it is morning, automatically it will be tea with milk), and then, with one graceful movement passes the drink always on an obligatory small tray, to the customer. Payment is usually made after the service.

The women start work at the crack of dawn - as everybody starts their day with a cup of tea (milk being a necessity) - and ends in the afternoon. Some women continue to work after dusk (if there is a restaurant or an important transport point nearby). Some do shifts: one in the morning, another in the afternoon. This might suggest some sort of partnership. All equipment is carefully packed into several baskets and taken away and there is a rule, she is helped by her children.

Looking at the phenomenon from the perspective of a city street, it must be remarked upon that the tea women give the street a complex character. Thanks to them, there is a space for work, but also for non-work. Thanks to the presence of these women, the street becomes a type of a social structure, mirroring normal life. Due to the ladies the street becomes alive, but also becomes a place of integration. Customers are passerbys, but above all employees of local shops, who often spend the vast part of their day in such shops. Finally, the coffee shops make the Sudanese street not only Muslim, but also African. Since they are run - in contrast to Middle Eastern countries - only by women, drinking tea or coffee has also become a Muslim tradition, an element of a specifically Islamic style of life.

\title{
WOMEN AND THE HERITAGE OF SLAVERY
}

\begin{abstract}
"Tea ladies" are not only a manifestation of the female informal economy in an urban environment, but also a phenomenon that throws some light on the relationships between the citizens of Sudan, particularly between the lighter-skinned, emanating from Arab and Muslim culture, and their darker-skinned counterparts, living in the outermost regions of the country. As mentioned earlier, the institution of tea ladies expresses patterns of power relations in the society of Sudan. It exposes the iconography of power, which is very characteristic of the modern world - although camouflaged in operation. The relics of slavery can be found in this setting since tea ladies are not fully free, and they are forced to play certain roles which used to be the domain of slaves.
\end{abstract}

In this particular context, ethnicity is very important. The client of a teahouse is, in the end, an Arab-Nubian, a Muslim, a resident of central or northern provinces. $\mathrm{He}$ is a consumer / customer. An African is a service provider. There is a patron-client relationship which goes back to the former institution of slavery. The customer of the cafe is a fully-fledged resident of Sudan, enjoying full political rights and with a sense of entitlement to power and privilege. This is the political aftermath of racist Arabism and politicized Islam, as well as many centuries of prejudice and slavery. The service 
provider (the tea lady) is a migrant, economic / war refugee who can only function on the margins of economic life. It is not only about economic reality, but also about race. The tea lady is simply blacker, and therefore "worse", "more primitive" and "less worthy". And it comes from the periphery. This fact is unmistakable in Sudan. From the periphery, the Nuba Mountains, or the borderlands with Ethiopia, slaves were brought in. Such people will never equate with the status of others and there is nothing that can change it neither faith nor profession. For a long time, as has already been mentioned, in Sudan status is closely related to geography. This is one of the main causes of antagonism in this country. Jealous city officials or uniformed personnel have repeatedly declared war on street cafes. The women have been driven away and their premises confiscated. I am of the opinion that these actions, can also be attributed to the community. These actions were measured not so much in the gray market as in the local migrants from peripheral areas with allegations of "colonizing" the urban space. I am of the opinion the actions undertaken by the authorities can be seen as a struggle for space and the restoration of the social order as dictated by tradition as the women's presence can be seen as their claiming to be on a par with the local community and thus equal to them.

Gender and the economy are also important here. As is known perfectly well, masculinity and femininity often reflect relations of power. And the division of labour, in addition to the law and ideology, is one of the spheres of gender dominance. Roadside cafes are part of the informal economy where tea-makers, though widely tolerated, work illegally. From a legal point of view, they have no rights, being at the mercy of their immediate environment. At the same time everyone, from a police officer to an average customer, is male. The tea ladies are pagan, unmarried and uncircumcised - in short, shameless. They are not seen as mothers or sisters, but as African women from the periphery; in other words a stereotypical slave. In former times, slaves, were allowed to partake in small trade or services. They were especially known for the production and sale of alcohol, which, among both "heathens" and Muslims alike, was once in widespread demand. This allowed them to possess certain professional and moral freedom, which no self-respecting Muslim woman would countenance. This state of affairs at the same time strengthened negative stereotypes of African women from the interior (Barclay 1964, 240). It is quite likely that the modern cafes of today originate from this tradition, with the only difference that instead of slaves in them only poor, migrant women are to be found. And, instead of alcohol, they sell only acceptable beverages such as tea and coffee. There is also a sexual dimension in all of this. In the popular imagination of the Sudanese, women originating from slavery-based families are associated with prostitution. In the times when slavery was practiced, women from the South were employed to work, but also valued sexually; they often became concubines or the successive wives of their owners. Through the system of commonlaw marriage with slaves, the process of biological and cultural assimilation began. 
After the death of her owner, the slave woman was generally granted freedom, and her children inherited a certain part of the estate. Even today, negroes from the South are considered the quintessence of feminine beauty. Similarly, the sexually loose stereotype is transferred to all women from the South, in particular to migrant women from the country, with an unclear family situation. For women from - what are perceived to be - "normal" homes they are a challenge as they bring to mind old feelings of fear associated with the presence of beautiful, black, uncircumcised slaves. Thus, in the work of roadside café women can be found relations of subordination, servility and even sexual violence (it is an open secret that women who provide sexual services also run cafes serving tea and coffee).

There are strict rules in cafeteria culture which emphasise situations of extreme inequality. None of the women work alone or independently. Each tea shop works in association with a restaurant or a shop. Formally, a woman is not a slave, but practically, she is not free either. There is no space here for her culture, language or community. There is kindness and friendship in the form of regular customers. However, there is no question of partnership or understanding. Everything is subordinated to one Islamic model. Muslim etiquette applies and communication takes place exclusively in Arabic. African identity and custom are suspended. In this context, it is post-slave in character, carrying with it relations of domination and subordination. It is a metaphor and a reminder of the near caste arrangements which still hold sway in Sudan.

\section{CONCLUSION}

Coffee shop culture manifests master/servant practices dating back to the times when there was slavery in Sudan. It is used to establish hierarchy, rivalry or to legitimise status. A stake or prize appears. For the stronger party a reward entails a status of superiority. The stake the woman is fighting for is to avoid humiliation, notwithstanding her meagre earnings. In this context the institution of tea shops has a post-slavery character and it engenders a relationship of dominance and subordination in a particularly antagonistic version. Using terms from structural anthropology - a series of oppositions are materialized: formal / informal, male / female, dominant / subordinate and Middle Eastern / African. They all help town citizens (mostly representatives of the Arab and Muslim majority) to establish hierarchy, rivalry or to express identity. Finally, they have great significance in the political arena - in collective mobilization, as well as the stigmatization of entire social groups - in this particular context migrants from distant periphery. This category is racialized with phenotypic features, such as skin color and hair structure being ascribed to them. 


\section{BIBLIOGRAPHY}

A $\mathrm{m}$ i r I. 20I3. Identity, Citizenship, and Violence in Two Sudans: Reimagining a Common Future. New York (https://books.google.pl/books?id=zXBtAAAAQBAJ\&printsec=frontcover\&dq=Idris,+Identity,+ Citizenship, + and + Violence+in + Two+Sudans: + Reimagining $+\mathrm{a}+$ Common + Future\&hl $=\mathrm{pl} \& \mathrm{sa}=\mathrm{X} \&$ ved=oahUKEwiy_rvwoaPdAhXDZVAKHeY_CnwQ6AEIKjAA\#v=onepage\&q= Idris\%2C\%20 Identity\%2 $\% 20$ Citizenship\%2C\%2Oand\%20Violence\%2oin $\% 20$ Two\%2oSudans $\% 3 \mathrm{~A} \% 20$ Reimagining\%20a\%20Common\%2oFuture\&f=false). Access: 15.09.2018.

B a les K. 1999. Disposable People. New Slavery in Global Economy. Berkley, Los Angeles, London.

B ales K., Trodd Z.A., Will i a m s on K. (eds). 20Ir. Modern Slavery. A Beginner's Guide. Oxford (https://books.google.pl/books?id=KQzaUorlLb8C\&printsec=froerkley ntcover\&dq=Kevin+Bales, + Zoe+Trodd,+Alex+Kent+Williamson+20II\&hl=pl\&sa=X\&ved=oahUKEwjIgo6Q8KbdAhXL PFAKHFM_AWgQ6AEIJzAA\#v=onepage\&q=Kevin\%2oBales\%2C\%2oZoe\%20Trodd\%2C\%20 Alex\%2oKent\%2oWilliamson\%2020II\&f=false). Access: 15.09.20I8.

B a les K. 2005. Understanding Global Slavery. A Reader. Berkley, Los Angeles, London.

B a r cl a y. B. 1964. Buuri al Lamaab: a Buburban Village in the Sudan. N. Y.

B reidlid A., S a id A. A., B re idlid A. K. (eds). 2014 ( $\mathrm{I}^{\text {st }}$ ed. 20Io). A Concise History of South Sudan. New and Revised Edition. Kampala.

J o h n s o n H. D. 201 ( ( $\mathrm{I}^{\text {st }}$ ed. 2003). The Root Causes of Sudan's Civil Wars. Suffolk.

J o k M. J. 200I. War and Slavery in Sudan. Philadelphia.

Ku rcz M. 2007. Za trzecia kataraktą. Poznań, Kraków.

$\mathrm{M} \mathrm{a} \mathrm{kr}$ is G. P. 2000. Changing Masters: Spirit Possession and Identity Construction among Slave Descendants and other Subordinates in the Sudan. Evanston.

Mu n z o u 1 A. S. A. 2orr. From the Country to the Town. In J. Ryle. J. Willis, S. Baldo, J. M. Jok (eds.), The Sudan Handbook. Suffolk. 63-70.

O'Connell Davidson J. 20I5. Modern Slavery. Margins of Freedom. Palgrave Macmillan (https://books.google.pl/books?id=HWekCgAAQBAJ\&printsec=frontcover\&dq=O\%6oConnell +Davidson+20I5\&hl=pl\&sa=X\&ved=oahUKEwixlJzho6jdAhXSarAKHf5TCecQ6AEIJzAA\#v=o nepage \&q=O\%60Connell\%20Davidson\%202015\&f=false). Access: 15.09 .2018 .

\section{List of illustrations}

photo I - A migrant from Nuba Hills, Ghaddar. Photo: M. Kurcz 2013. photo 2 - A "women of tea" on Forty Days Road Street, Omdurman. Photo: M. Kurcz 2013. photo 3-A women from the Madi tribe, one of the many societies of South Sudan affected by slavery, Juba. Photo: M. Kurcz 2008.

photo 4 - "Jallaba" - a merchant from Northern Sudan, Debba. Photo: M. Kurcz 2013. photo 5 - A place of work, Khartoum. Photo: M. Kurcz 2013.

\section{Author's address}

Maciej Kurcz PhD Hab., Univ. of Silesia Professor Institute of Ethnology and Cultural Anthropology Univeristy of Silesia in Katowice ul. Bielska 62, 43-40o Cieszyn, POLAND e-mail: maciej.kurcz@us.edu.pl ORCID: 0000-0002-9505-73II 
